NASA/TM-2000-210243

\title{
Solar Power System Options for the Radiation and Technology Demonstration Spacecraft
}

Thomas W. Kerslake, Francis M. Haraburda, and John P. Riehl

Glenn Research Center, Cleveland, Ohio

Prepared for the

35th Intersociety Energy Conversion Engineering Conference sponsored by the American Institute of Aeronautics and Astronautics

Las Vegas, Nevada, July 24-28, 2000

National Aeronautics and

Space Administration

Glenn Research Center 


\section{Acknowledgments}

The authors would like to acknowledge Mr. Leon Gefert of NASA Glenn Research Center for his contributions to the trajectory analysis, Mr. Scott Benson, NASA Glenn RTD Project Manager for his valuable technical suggestions and Mr. H. James Fincannon of NASA Glenn Research Center for his valuable contributions to the spacecraft flight mode and attitude control assessment.

This report contains preliminary

findings, subject to revision as analysis proceeds.

Available from

NASA Center for Aerospace Information 7121 Standard Drive

Hanover, MD 21076

Price Code: A03
National Technical Information Service 5285 Port Royal Road Springfield, VA 22100

Price Code: A03 
AIAA-2000-2807

\title{
SOLAR POWER SYSTEM OPTIONS FOR THE RADIATION AND TECHNOLOGY DEMONSTRATION SPACECRAFT
}

\author{
Thomas W. Kerslake, Francis M. Haraburda, and John P. Riehl \\ National Aeronautics and Space Administration \\ Glenn Research Center \\ Cleveland, $\mathrm{OH} 44135$
}

\begin{abstract}
The Radiation and Technology Demonstration (RTD) Mission has the primary objective of demonstrating high-power (10 kilowatts) electric thruster technologies in Earth orbit. This paper discusses the conceptual design of the RTD spacecraft photovoltaic (PV) power system and mission performance analyses. These power system studies assessed multiple options for PV arrays, battery technologies and bus voltage levels. To quantify performance attributes of these power system options, a dedicated Fortran code was developed to predict power system performance and estimate system mass. The lowthrust mission trajectory was analyzed and important Earth orbital environments were modeled. Baseline power system design options are recommended on the basis of performance, mass and risk/complexity. Important findings from parametric studies are discussed and the resulting impacts to the spacecraft design and cost.
\end{abstract}

\section{INTRODUCTION}

Various electric propulsion systems have been flying on spacecraft since the $1960{ }^{1} \mathrm{~s}^{1}$. Because of their low mass and high specific impulse (Isp), electric propulsion systems are being baselined on an ever increasing number of missions. To keep mission trip times manageable, higher thrust levels are desirable with an attendant increase in spacecraft power level. Power levels in the $10^{\prime}$ 's of kilowatts $(\mathrm{kW})^{2,3,4}, 100$ 's of $\mathrm{kW}^{5}$ and even 1000 's of $\mathrm{kW}^{6.7 .8}$ have been proposed to operate electric thruster systems.

To enhance the flight readiness of high power electric propulsion systems, the Radiation and Technology Demonstration (RTD) Mission ${ }^{9}$ is under joint study by three NASA Centers: Johnson Space Center, Goddard Space Flight Center and Glenn Research

Copyright $(2000$ by the American Institute of Aeronautics and Astronautics, Inc. No copyright is asserted in the United States under Title 17. U.S. Code. The U.S. Government has a royalty-free license to exercise all rights under the copyright claimed herein for Governmental Purposes. All other rights are reserved by the copyright owner.
Center. This Earth-orbiting mission, that may launch on the Space Shuttle within the next 5 years, has the primary objective of demonstrating high-power (10 kW) electric thruster technologies. Secondary scientific objectives include: better characterization of Earth's Van Allen trapped radiation belts, measurement of shielding effectiveness for human protection from trapped radiation and galactic cosmic radiation, measurement of radiation effects on advanced solar cells, demonstration of radiation tolerant microelectronics and measurement of the interactions between the spacecraft and its ambient environment.

The 1500-kilogram (wet) RTD spacecraft, shown in Figure 1, consists of a spacecraft bus, the Hall thruster system ${ }^{3.4}$ on top, the VAriable Specific Impulse Magnetoplasma Rocket (VASIMR) thruster system $^{10}$ on the bottom and a microsatellite stowage/deployment system located in the spacecraft midsection. The spacecraft bus includes a solar Electric Power System (EPS) that is dominated by two deployable, rectangular photovoltaic array wings with single-axis Solar Array Drive Assemblies (SADAs) for solar tracking.

This paper will discuss the RTD mission trajectory analysis, the conceptual design of the RTD spacecraft photovoltaic (PV) EPS and predicted EPS mission performance for the various power system options. Baseline solar EPS design options are recommended on the basis of performance, mass and risk/complexity. Important findings from parametric studies are discussed and the resulting impacts to the spacecraft design and cost.

\section{MISSION TRAJECTORY ANALYSIS}

The two mission scenarios presented herein represent the latest iteration in the design process whereby spacecraft mass and mission duration are traded for scientific and research objectives. During the proposed mission duration of about 270 days, the RTD spacecraft spirals outward from the Shuttledeployed, circular low Earth orbit. During the planar 
spiral out at an orbit inclination of $28.45^{\circ}$ or $51.6^{\circ}$, four microsatellites will be deployed to provide simultaneous radiation measurements of various $V$ an Allen belt locations. By the phased operation of the $10 \mathrm{~kW}$ Hall thruster and $10 \mathrm{~kW}$ VASIMR, the RTD spacecraft will attain an orbit radius greater than 5 Earth radii. The Hall thruster, because of its lower specific impulse (Isp), produces relatively short transfer times while requiring more propellant whereas the VASIMR thruster, with its very high Isp, produces very long transfer times and uses very little propellant. To control mission cost, the overall mission must be performed in no more than one year. All of these competing needs produce a mission that is at best a compromise. Mission requirements and thruster system performance for RTD are summarized in Table 1.

Trajectory analysis for this kind of mission is initially rather straight forward. Using Edelbaum's expression for optimal minimum time transfer between circular orbits, one can compute the velocity increment, $\Delta \mathrm{V}$, to transfer from an initial circular orbit with velocity $V_{1}$ to a final circular orbit with velocity $V_{2}$ while performing a plane change of $\Delta \mathrm{i}$ :

$\Delta V=\left\{V_{1}^{2}+V_{2}^{2}-2 V_{1} V_{2} \cos (\pi / 2 \Delta i)\right\}^{1 / 2}$

When used with the "Rocket" equation,

$\mathrm{m}_{\mathrm{f}} / \mathrm{m}_{0}=\exp \left(-\Delta \mathrm{V} / \mathrm{gI}_{\mathrm{sp}}\right)$

one has a means for estimating propellant consumption, $m_{0}-m_{f}(\mathrm{~kg})$, and thrusting time (seconds) because thrust, T (Newtons), Isp (seconds), thruster efficiency, $\eta$, and input power level, $P_{0},(W)$ are related by:

$\mathrm{T}=2 \eta \mathrm{P}_{0} /\left(\mathrm{gI}_{\mathrm{sp}}\right)$

while the

Transfer Time $=\left(m_{0}-m_{f}\right) /$ mass flow rate.

These expressions demonstrate the inherent interaction between the spacecraft trajectory, electric propulsion performance and power system performance.

To estimate the impact of shadowing and launch date on the performance, the computer program SEPSPOT $^{17}$ is used. This program uses orbital averaging and solves for the minimum time trajectory between two closed conic orbits. This combination of resources, namely spread sheets which incorporate the above expressions and the SEPSPOT program, permits the determination of preliminary mission durations and altitudes at which to switch from one thruster to another. This allows one to simulate a mission in much more detail and fidelity. The results presented herein are derived from trajectories generated using the Glenn Research Center's high fidelity integrator SNAP which incorporates an eighth order Runge-Kutta integrator, the AE8 and AP8 trapped radiation models ${ }^{12}$, and the JPL DE403 Ephemeris file of the solar system. Earth shadow crossings are precisely modeled and an eighth order earth gravity model is used along with solar and lunar gravitational effects. The vehicle is assumed to steer with tangential steering, but no attempt is made to remove eccentricity that accumulates because of discontinuous thrusting when crossing into and out of shadow regions. It is further assumed that the EPS provided a constant $10 \mathrm{~kW}$ of power to the thrusters during orbit sun times. The microsat masses are jettisoned at the prescribed altitudes at perigee.

Spacecraft Flight Mode

The nominal flight mode has the RTD spacecraft thruster-axis in the orbit plane and tangent to the orbit ellipse. The solar array wings are perpendicular to the orbit plane and rotate about a single axis. This nominal flight mode is used for absolute solar beta angles, $|\beta|$, less than $25^{\circ}$, where $\beta$ is the angle between the orbit plane and Earth-Sun line. During this flight mode, solar array cosine pointing losses are limited to $9 \%$.

For $|\beta|$ greater than $25^{\circ}$, the spacecraft switches to a so-called "yaw-steering" flight mode utilized by several other spacecraft ${ }^{13-16}$. For the RTD spacecraft, the flight mode is more properly called "roll-steering" as the spacecraft rolls about the thruster axis (maintained in plane and tangent to the orbit ellipse). This type of spacecraft steering was studied for a solar electric transfer vehicle mission ${ }^{17}$. Using momentum wheels, the spacecraft is rolled through an angle $\leq 2\left(90^{\circ}-|\beta|\right)$ in one-half orbit period. The combined spacecraft roll angle and single axis SADA rotation enables sun-tracking array pointing. The implications of this flight mode for spacecraft attitude control system (ACS) design will be discussed later in the paper.

\section{EPS DESIGN OPTIONS}

Photovoltaic Array

Nine different PV array design options were evaluated and are briefly described in Table 2 . Options 1 and 2 are typical of deployable rigid-panel designs with cascade (or multi-junction) 
GaInP2/GaAs/Ge solar cells ${ }^{18}$ used on communication satellite buses, such as the $\mathrm{A} 2100^{19}$ and $\mathrm{HS}_{702^{20}}$. Panels are constructed of composite face sheets bonded to a 1-inch thick aluminum honeycomb core. The HS702 arrays also deploy side reflectors to achieve about $2 \mathrm{X}$ solar concentration on the solar cells. Options 3,4 and 5 are mastdeployable, flexible composite panel designs using multi-junction GaInP2/GaAs/Ge solar cells, high efficiency silicon cells ${ }^{21}$ or three-junction amorphous SiGe cells ${ }^{22}$ on stainless steel panels. Options 6 and 7 use multi-junction GaInP2/GaAs/Ge solar cells operating under $7.5 \mathrm{X}$ solar illumination afforded by rigid refractive linear concentrators on deployable rigid panels or flexible refractive linear concentrators on mast-deployable flexible panels ${ }^{23}$. The former array type is successfully flying on the Deep Space 1 Mission spacecraft ${ }^{24}$. Options 8 and 9 employ a multi-gore array design that deploys circumferentially to form a quasi-circular, array geometry ${ }^{25}$. The gore material is a low-mass open-weave fabric. The multi-junction GaInP2/GaAs/Ge solar cells or the high efficiency silicon cells populate the gore sections. Array wings similar to option 9 have been built for an up-coming Mars Lander mission ${ }^{26}$. In all options, each solar array wing is mounted to a singleaxis SADA with slip ring power transfer.

\section{Energy Storage}

Both nickel-hydrogen $(\mathrm{NiH} 2)$ individual pressure vessel and prismatic lithium ion battery cell technologies were considered to fulfill energy storage requirements. Cell properties, such as charge/discharge voltage limits, dimensions, mass, and operating temperature range, were obtained from typical values found in commercial battery product data sheets (see Table 3). For this mission, a modest 1000 -cycle cell life was required. Cells were seriesconnected and housed in an aluminum containment box to afford environmental protection and enhance thermal control.

PMAD Architecture, Loads and Power Requirements End-of-mission power system requirements included 10 $\mathrm{kW}$ of sun time power delivered to the electric thruster Power Processing Unit (PPU) input and $0.4 \mathrm{~kW}$ delivered to spacecraft loads continuously through sun and eclipse times. The maximum eclipse time for this mission was 1.14 hrs. This translated to an energy storage requirement of $0.46 \mathrm{~kW}$-hrs exclusive of system losses. Power system reliability and fault-tolerance requirements have not been yet specified. As such, the Power Management And Distribution (PMAD) architecture does not include design features to address these operational requirements.
The direct energy transfer, direct current (DC) power distribution architecture, as shown in Figure 2, provides sun time regulated primary power for the operating thruster and for battery charging. Sun time and eclipse time regulated secondary power at 28 VDC is provided to the spacecraft loads. The power generation of each solar array wing (discussed in detail below) is controlled by a sequentiallyshunted, pulse-width-modulated, Array Regulator Unit (ARU). Approximately $5.5 \mathrm{~kW}$ is transferred from each solar array wing through the ARU and is paralleled at the input of the Main Distribution Panel (MDP). The MDP contains all of the associated fault detection and isolation hardware for the individual power feeds to the vehicle loads, the capability to isolate solar arrays, the required power supply and control processor. Primary distribution bus set point voltages of $120 \mathrm{VDC}, 50 \mathrm{VDC}$ and $28 \mathrm{VDC}$ were assessed. These voltage levels were chosen to allow use of existing components $(120-\mathrm{V}$ space station. $28-\mathrm{V}$ typical satellites) or to match the operating voltage, $50-\mathrm{V}$, of the VASIMR radio frequency plasma generators ${ }^{10}$.

Grounding of the system negative return will be made in the MDP. The switchgear used in the MDP will be similar to those used in Space Station hardware, which uses a 120 VDC secondary architecture. The MDP power supply will receive input power from the MDP power bus and from the vehicle battery for the eclipse portions of the orbit. Isolation between the two feeds will be provided for.

RTD vehicle and experiment load power will be provided using a proven design similar to that used for the Microwave Anisotropy Probe mission ${ }^{27}$. The Power System Enclosure (PSE) will provide power conditioning, switching, SADA control, fault detection and isolation for vehicle subsystems and instrumentation. It will accept power from the MDP to charge the battery and to power loads through a DC-to-DC converter unit.

Each of the vehicle's two thrusters is shown with an accompanying PPU. The PPU will be used to condition the input power to the voltage/current requirements of the various loads associated with the thruster. The PPU will consist of converters with the ability to isolate failed components of the thruster and isolate load effects from the vehicle power system. Thruster startup and maintenance power will be provided via 28 VDC secondary power. The actual power requirements for these loads and their number have yet to be determined. 
PMAD cable sizes were selected based on the assumed number of vehicle loads, run lengths, number of parallel conductors (two-hot, two-two ground), operating temperature $\left(100^{\circ} \mathrm{C}\right)$. The sizes shown in the power architecture (Figure 2) were selected based on the assumed load power requirements. Those shown were rated using the Mil-W-22759D specification for cables in hard vacuum and current derating due to bundling.

\section{ANALYSIS \& COMPUTATIONAL METHODS}

To assess the relative merits of these PV array and PMAD design options, a dedicated Fortran code was developed to predict power system performance and estimate system mass. EPS component design and mission information are read in via data input files. Mission data, provided at 15-minute intervals throughout the 270-day mission, include spacecraft position/velocity, Sun/Earth angles, orbit sun/eclipse indicator, insolation strength and local radiation fluences. This information is used to calculate environmental heating rates, solar cell equivalent radiation dose $\mathrm{e}^{28.29}$ and solar cell micrometeoroid/ orbital debris damage area $a^{30-34}$.

EPS performance analysis is performed in a timestepping, load-driven fashion. Based on load demand and setpoint voltages, PMAD system currents and voltages are calculated for the current time step. Component and cable losses are calculated based on input resistances, diode voltage drops and converter efficiency (if present). PV array string current is iteratively determined to satisfy solar cell and ARU voltage and current constraints. The number of string series-connected solar cells is determined iteratively such that cell operating voltage becomes no larger than maximum power voltage throughout the mission. The number of strings per wing is also determined iteratively such that minimum number of shunted strings is $<3$. This minimizes array area while ensuring that the ARU can maintain sun time voltage regulation throughout the mission.

Solar cell electrical performance is modeled using a single exponential current-voltage (IV) function that is adjusted for operating temperature, illumination intensity, PV array sun pointing error and flatness, coverslide transmittance, environmental degradation and cell mismatch. Solar cell IV operating point and temperature are iteratively determined. Cell operating temperature is calculated using a lumpmass, transient thermal model accounting for environmental heating/cooling, electrical power extraction and interconnect wiring ohmic heating. Array area is calculated as the total solar cell area divided by a packing factor, 0.85 . A wing length-to- width ratio of 6 was selected to obtain a width of approximately $2-\mathrm{m}$ that corresponds to the approximate length of the spacecraft microsat storage section (see Figure 1).

The battery is sized based on the input design characteristics of Table 3 . These inputs are used to calculate the number of cells, cell capacity, design Depth-Of-Discharge (DOD), design charge/discharge rates and trickle charge rate. For mission analysis, the battery charge and discharge rates are determined based on the required load, battery charge and discharge efficiencies and the orbit sun and eclipse time. For orbits with little or no eclipse period, the battery charge current is set to a trickle charge value (C/50).

The temperature of several EPS components is also calculated using a simplified, lumped-mass transient model. Calculated values of component power dissipation and environmental heating are used to determine operating temperature and the required thermal control heating or cooling to satisfy operating temperature limits.

\section{Mass Estimation}

PV array mass was comprised of panels, structures/mechanisms/miscellaneous, power harness and the SADA. Panel masses were calculated for each array option based on panel layer material thicknesses, densities and areal fractions (see Table 2). Array structure and mechanism masses were estimated to be $10 \%$ of the panel mass (for rigid concepts), $0.6 \mathrm{~kg} / \mathrm{m} 2$ for deployable mast concepts and $0.3 \mathrm{~kg} / \mathrm{m} 2$ for multi-gore concepts. Power harness mass was based on a commercial flat ribbon design sized for $3 \%$ voltage drop. The SADA mass was based on a commercial product. The battery mass was calculated to be 1.1 times the cell mass to account for cell interconnects, by-pass diodes, cell voltage control ( $\mathrm{Li}$-ion only), cell heaters, the containment box and connectors. PMAD component masses were based on scaling ISS EPS component masses and power levels: ARU (2 kg/kW), MDP $(2 \mathrm{~kg} / \mathrm{kW})$, and PSE $(9 \mathrm{~kg} / \mathrm{kW})$. Cable conductor masses, from Mil-W-22759D, were multiplied by 1.1 to account for insulation mass. PMAD component and battery thermal control were achieved via thermal control coatings (no mass assumed) and electric resistance heaters (included in component masses).

\section{MISSION PERFORMANCE RESULTS}

Selected mission and EPS performance analysis results are discussed in this section for an initial baseline EPS design and orbit defined as follows: 
- Option 1 solar array (rigid panels, cascade GaAs cells)

- NiH2 Battery

- 120 VDC PMAD Primary Voltage

- $51.6^{\circ}$ orbit inclination

Figure 3 shows the spacecraft orbit altitude throughout the 270-day mission. Lack of smoothness in this curve was due to a small buildup of orbit eccentricity (about $5 \%$ ) that resulted from only thrusting during orbit sunlight periods. Solar array wing power is shown in Figure 4. The top curve shows the full wing power with no strings shunted while the bottom curve shows power delivered by the array through the ARU to the MDP. The difference between the two curves was the power shunted in the ARU. Most of the power degradation occurred between mission days 50 and 100 while the spacecraft was passing through the trapped radiation proton belts. As shown in Figure 5, during this period of time, most of the solar cell current capability was reduced due to radiation degradation. Other current reducing factors are also shown on Figure 5. Similar behavior was seen with solar cell voltage degradation, i.e. the largest degradation mechanism was radiation damage.

The ratio of solar cell operating voltage, Vop, to maximum power voltage, $\mathrm{Vmp}$, is displayed in Figure 6. At the mission start, the ratio ran at about 0.9 since the number of series solar cells must be oversized for degradation. After receiving the bulk of radiation damage, the voltage ratio approached 1.0. Thereafter, it decreases slightly as array temperatures cooled off with increasing spacecraft altitudes and solar cell voltage capability was improved.

EPS component temperatures are given in Figure 7. The solar array operated at suntime temperatures of about $47^{\circ} \mathrm{C}$ at the mission start to $35^{\circ} \mathrm{C}$ at mission end. Array eclipse temperatures reached $-120^{\circ} \mathrm{C}$ 90 -days into the mission at orbit altitudes of about $7000 \mathrm{~km}$. Thereafter, the spacecraft did not encounter eclipse periods. PMAD components remained within a modest temperature envelope: $0^{\circ} \mathrm{C}$ to $75^{\circ} \mathrm{C}$ at the mission start and $5^{\circ} \mathrm{C}$ to $10^{\circ} \mathrm{C}$ at mission end.

\section{PARAMETRIC STUDY RESULTS}

Parametric studies were performed to assess EPS performance and mass versus several system design options and mission operation options. The primary objectives of these studies were to minimize spacecraft mass and to quantify impacts of various mission operation scenarios. The parametric trade space is shown in Table 4. The initial baseline EPS design and orbit were defined in the previous section. These items were used in the following parametric studies unless noted otherwise.

\section{Coverslide Thickness}

The first parametric study conducted was EPS mass versus solar cell coverslide thickness. Coverslide thickness affects many properties including radiation shielding, transmittance, solar cell operating efficiency, solar array panel areal mass and thermal capacitance and solar cell operating temperature. Thus, an iterative EPS sizing and performance analysis must be performed for each case of coverslide thickness to ensure power requirements are met. The normalized results from EPS sizing analyses are shown in Figure 8.

EPS mass (and solar array mass) was minimized with a 10-mil coverslide thickness. Greater thicknesses decreased the solar cell Damage Equivalent Normally Incident (DENI) mission fluence of $1-\mathrm{MeV}$ electrons, decreased array area and increased cell beginning-oflife (BOL) operating efficiency, i.e. the cell operating voltage was closer to the maximum power point voltage. However, these benefits came at the expense of greater EPS mass. Thus, a 10-mil coverslide thickness was baselined.

As an aside, the optimum coverslide thickness for GaAs cells mounted to a flexible substrate, with lower backside shielding than that of rigid panels, would be thicker. Also, if silicon cells were assumed, the effective transmittance loss of thicker coverslides would be reduced since most transmission losses are in the blue region away from the peak spectral response of silicon cells. This effect would lead to greater optimum coverslide thicknesses for silicon cells compared to GaAs cells.

Photovoltaic Array Technology

EPS sizing analyses were performed for the baseline design and mission operation conditions for each of the nine solar array options. Results are shown in Table 5. The baseline EPS had a mass of $258 \mathrm{~kg}$ comprised of a $167 \mathrm{~kg}$ array, $36 \mathrm{~kg} \mathrm{NiH} 2$ battery and a $55 \mathrm{~kg}$ PMAD system. The solar array had two wings, each with an area of $24.9 \mathrm{~m} 2$.

The lowest EPS mass, $180 \mathrm{~kg}$, and lowest solar array mass, $89 \mathrm{~kg}$, were provided by option 7 (flexible panel, flexible concentrator, GaAs cells). A power system mass savings $78 \mathrm{~kg}$ over the baseline design was achieved. Option 2 (rigid panel with side reflectors, GaAs cells) and option 8 (flexible gore, GaAs cells) were also strong low-mass contenders with EPS masses of $188 \mathrm{~kg}$ and $195 \mathrm{~kg}$, respectively. 
The highest EPS masses, $298 \mathrm{~kg}$ and $313 \mathrm{~kg}$, were obtained with options 4 and 9 , respectively, which both use high efficiency silicon cells. During the mission, these solar cells received a very high radiation dose $\left(4 \times 10^{15} \mathrm{e} / \mathrm{cm}^{2}\right)$. This dictated that the array had to be oversized considerably to make-up for radiation degradation losses. For this reason, crystalline silicon cells are not a good choice for the RTD mission.

The smallest array wing area, $23.5 \mathrm{~m} 2$, was obtained with option 6 (rigid panel, rigid concentrator, GaAs cells). The option had the highest areal mass and provided excellent radiation shielding for the solar cells, i.e. dose of only $2 \times 10^{14} \mathrm{e} / \mathrm{cm} 2$. As such, cell radiation losses were small and array oversizing was minimal. The option 2 array (rigid panel, side reflectors, GaAs cells) had the smallest solar cell panel area. However, when including the area of the side reflectors, the wing frontal area increased to $29.5 \mathrm{~m} 2$ which was the largest of the array options using GaAs cells.

The option 5 array (amorphous SiGe thin film cells on stainless steel) did not provide a design solution for this mission. The reason for this was twofold: high radiation degradation and high operating temperature. Both of these factors lowered the cell operating efficiency to below $3 \%$ at 150 -days into the 270-day mission. At this point, stable solar cell string operation could not be obtained. At the expense of added mass, the thin film panel could be encapsulated with a fluoropolymer to provide radiation shielding and improve surface emittance to lower cell operating temperature. In the longer term, alternative thin film technologies, such as $\mathrm{Cu}(\mathrm{In}, \mathrm{Ga}) \mathrm{Se} 2$ or $\mathrm{Cu}(\mathrm{In}, \mathrm{Ga}) \mathrm{S} 2$ on a polymer substrate, promise higher stable conversion efficiencies, greater radiation tolerance and lower areal mass compared to three-junction amorphousSiGe thin film cells on a stainless steel substrate. An excellent assessment of the benefits of thin film photovoltaic arrays was reported by Hoffman ${ }^{35}$.

\section{Battery Technology}

Preliminary battery designs were developed based on $\mathrm{NiH} 2$ and $\mathrm{Li}$ ion cell technologies. Design results are shown in Table 6 . The $\mathrm{Li}$ ion cell option provided a $23 \mathrm{~kg}$ battery mass savings over the $\mathrm{NiH} 2$ cell option in addition to a considerable reduction in battery volume. For both battery technologies, preliminary values of heater power and cooling load were negligible to maintain operating temperatures within design limits. Assuming cell capacity loss is minimal during 1000 cycles of operation at $50 \% \mathrm{DOD}$, the $\mathrm{Li}$ ion battery technology is clearly preferred over the $\mathrm{NiH} 2$ technology from a performance standpoint.

\section{PMAD Primary Voltage}

EPS design sizing and performance were analyzed for primary PMAD voltage set points of $120-\mathrm{V}, 50-\mathrm{V}$ and 28-V. Results are provided in Table 7 . The most obvious effect of reducing primary voltage was a large increase $(64 \%)$ in power system mass, i.e. from $258 \mathrm{~kg}$ at $120-\mathrm{V}$ to $424 \mathrm{~kg}$ at $28-\mathrm{V}$. For most system components, mass increased with decreasing voltage due to higher operating currents, larger voltage drops and larger physical size. In the array, size and mass increased for panels, structure, power harness and the SADA. For PMAD components, the bulk of the mass increase was from the ARU that would require a $3 \mathrm{X}$ to $4 \mathrm{X}$ increase in the number of shunt channels. PMAD cable mass increased as the number of parallel conductors was increased to satisfy increased derated current requirements. For example, the PPU input current increased from $84 \mathrm{Amp}$ at $120-\mathrm{V}$ to $382 \mathrm{Amp}$ at $28 \mathrm{-V}$. Higher PPU currents would also increase the PPU mass not addressed in this paper (tallied with the propulsion system budget).

The only exception to the trend of increasing mass was the battery. Battery mass decreased for the lower voltage cases since it was possible to better match the required cell capacity with commercially available $10 \mathrm{~A}$-hr, $20 \mathrm{~A}-\mathrm{hr}$, etc., capacity cells. For example, the $120-\mathrm{V}$ system required a $6 \mathrm{~A}$-hr cell for which a $10 \mathrm{~A}-\mathrm{hr}$ standard cell sized was specified.

With decreasing PMAD voltage, the required solar array wing area also increased ( $27 \%$ ) from $24.9 \mathrm{~m} 2$ at $120-\mathrm{V}$ to $31.7 \mathrm{~m} 2$ at $28-\mathrm{V}$. The $28-\mathrm{V}$ system had increased voltage losses in the power harness, SADA, PMAD components and cabling. This dictated that array strings operate at a higher voltage relative to the setpoint voltage level. To satisfy the power requirements, many more array wing strings were required, i.e. from 138 strings at $120-\mathrm{V}$ to 624 strings at $28-V$. With this many strings, panel solar cell laydown pattern and string-power harness integration would become increasingly complex.

To minimize system mass, array area and array wiring complexity, a $120-\mathrm{V}$ power system is a clear winner. In the future, even better mass performance will be possible using a high-voltage EPS (400-V for Hall thrusters) and "direct-drive" electric thruster operation: that is, using a less complex PPU without a step-up voltage converter ${ }^{36}$. 
Orbit Inclination

EPS sizing and performance were analyzed for planar spiraling mission trajectories with orbital inclinations of $51.6^{\circ}$ and $28.45^{\circ}$. Results showed that orbit inclination in the range of $28.45^{\circ}$ to $51.6^{\circ}$ had little impact on EPS design and performance. At $28.45^{\circ}$, the EPS mass was about $5 \mathrm{~kg}$ more than that at $51.6^{\circ}$ primary due to an increase in array mass. A slightly larger array was needed for the $28.45^{\circ}$ inclination orbit since the solar cell radiation dose was slightly larger, i.e. more mission time was spent passing through the proton belts. Also, the solar cell operating temperature was slightly higher due to a larger Earth view factor and the attendant higher array backside albedo and infrared heating fluxes.

\section{Impacts to ACS}

In addition to the high degree of synergism between the EPS and electric propulsion systems, there is a strong synergism between the spacecraft EPS and ACS. Specifically, the EPS solar array wings contribute to the bulk of spacecraft inertia and control the magnitude of environmental disturbance torques and the required roll torques to achieve the "roll steering" flight mode.

To quantify the consequence of array selection on the ACS design, spacecraft maximum disturbance torques $^{37}$ and roll steering torques were estimated. Contributing disturbances included gravity gradient, aerodynamic drag, thruster misalignment, solar pressure and magnetic in order of magnitude. Orbital momentum accumulation was also estimated. Results are shown in Table 8 for the most demanding part of the mission at a BOL orbit altitude of $400 \mathrm{~km}$.

Predicted roll steering torques were dominant over disturbance torques and consistent with those of Jenkin ${ }^{17}$. Combined torques were within the torque capability of commercial reaction wheels. Momentum accumulation would be managed via periodic hydrazine thruster firings. Assuming $50 \mathrm{~N}$ $\mathrm{m}$-sec wheels, wheel desaturation would be needed, in the worst case, about 30 times daily at BOL, 12 times daily after mission day 20 (1000 km altitude) and 9 times daily after mission day $50(5000 \mathrm{~km}$ altitude). Over the mission, wheel desaturation would require about $68 \mathrm{~kg}$ of hydrazine propellant. Since mission momentum accumulation was dominated by electric thruster misalignment torque, considerable hydrazine mass savings could be achieved using a Hall thruster gimbal system. At the expense of $55 \mathrm{~kg}$ of added mass, reaction wheel momentum could be doubled thereby reducing the required frequency of momentum dumps by a factor of 2. Aside from solar array options 4 and 9 that utilize silicon cells (and thus, have large areas and large inertias), there is not a clearly preferred option to reduce ACS mass or complexity.

\section{Spacecraft Benefits from EPS Mass Savings}

The RTD spacecraft has a wet mass to dry mass ratio of 1.4. Thus, for every $1 \mathrm{~kg}$ saved in spacecraft dry mass, $1.4 \mathrm{~kg}$ is saved in spacecraft wet mass. Based on these trade studies, the best possible EPS mass reduction would be to transition from the baseline design to solar array option 7 using a $\mathrm{Li}$ ion battery. This would provide mass savings of $101 \mathrm{~kg}$ for the EPS and $141 \mathrm{~kg}$ for the spacecraft including $30 \mathrm{~kg}$ (11\%) savings for Hall thruster xenon propellant and $5 \mathrm{~kg}(11 \%)$ savings for VASIMR hydrogen propellant.

Given the RTD spacecraft is launched by the Space Shuttle, spacecraft mass is not a critical design driver. Instead, spacecraft cost is probably the most important hardware design factor. EPS mass savings were mostly obtained by using an advanced technology solar array. Thus, cost savings associated with reduced array size are not likely to outweigh the multi-million dollar development and qualification costs required by an advanced, first-unit design. Also, a $11 \%$ propellant savings will not appreciably affect the propellant storage and delivery system design or cost aside from a modest savings in xenon propellant procurement cost.

Therefore, after this preliminary assessment, it appears that a commercially available EPS design would be the best option from a mission/spacecraft cost standpoint. However, the cost-benefit calculus may dramatically change in favor of a low-mass, high-technology EPS for spacecraft launched with expendable vehicles on high-energy trajectories (inter-planetary missions). Here, mass savings can be a critical cost factor and many times, a missionenabling factor.

\section{Final Baseline Options}

At both ends of the spectrum, two final baseline EPS options should be considered:

(1) For lowest cost and lowest risk at moderate mass, a final baseline EPS is the initial baseline EPS: that is, an option 1 rigid panel solar array with cascade GaAs cells, a $\mathrm{NiH} 2$ battery and a $120-\mathrm{V}$ PMAD system.

(2) For lowest mass, moderate risk, higher cost yet high technology demonstration value, a final baseline EPS design employs an option 7 flexible array with flexible concentrators, cascade $\mathrm{GaAs}$ cells, a $\mathrm{Li}$ ion battery and a 120-V PMAD system. 


\section{CONCLUDING REMARKS}

Several conceptual EPS designs were specified and analyzed with the intent of fulfilling RTD spacecraft and mission requirements while minimizing mass and cost. The spacecraft mission trajectory and the nature of EPS performance through a mission were described. The mass and performance benefits of various power system technology choices was quantified through parametric studies. From these, we concluded that solar cells should be glassed with 10-mil thick coverslides, $\mathrm{Li}$ ion battery cell technology is preferred over $\mathrm{NiH} 2$ technology and a $120-\mathrm{V}$ PMAD offers substantial mass/size savings over lower voltage systems. The impacts of EPS sizing on spacecraft ACS was examined and found not to be discriminatory. And finally, the benefits of spacecraft mass savings in the context of the RTD mission were assessed with the fundamental finding that low cost components are favored over low mass components. In the end, a lowcost, moderate mass EPS option and a low-mass, moderate cost EPS option were recommended.

\section{REFERENCES}

1. Sovey, James S., et al., "A Synopsis for Ion Propulsion I vevelopment in the United States: SERT I to Deep Space I," NASATM-1999-209439. Oct 1999.

2. Oleson, Steve, "Advanced Electric Propulsion For RLVLaunched Geosynchronous Spacecraft," NASA/TM-1999. 209646. Dec 1999.

3. Jankovsky. Robert S., et al., "Preliminary Evaluation of a $10 \mathrm{~kW}$ Hall Thruster," NASA/TM-1999-209075, Apr 1999.

4. Jacobson, D. and Jankovsky, R., "Performance Evaluation of a 50 kW Hall Thruster," AIAA 99-0457, 37 $7^{\text {th }}$ AIAA Aerospace Sciences Meeting and Exhibit, Reno, NV. Jan 11-14, 1949.

5. Oleson, Steve, "Advanced Electric Propulsion For Space Solar Power Satellites," NASATM-1999-209307. Aug 1999.

6. Kerslake, Thomas W., and Gefer, Leon P., "Solar Power System Analyses for Electric Propulsion Missions," $34^{\text {th }}$ Intersociety Energy Conversion Engineering Conference, SAE99-01-2449, Vancouver, British Columbia, Canada. Aug 1-5. 1999. (see also NASATM-1999-209289).

7. Gefert. Leon P.. Hack, Kurt J., and Kerslake, Thomas W., "Options for the Human Exploration of Mars using Solar Electric Propulsion," AIP Conference Proceedings. No. 458, STAIF-99, January 1999, p. 1275-1280.

8. Dudzinski, Leonard A.. Hack. Kurt J.. Gefert, Leon P. and Kerslake, Thomas W.. "Design of a Solar Electric Propulsion Transfer Vehicle for a Non-Nuclear Human Mars Exploration Architecture," $26^{\text {th }}$ International Electric Propulsion Conference, paper IEPC-99-181, Kitakyushu, Japan. October 17-21, 1999.

9. Kerslake. Thomas W, and Benson. Scott W.. "Power System Options for the Radiation \& Technology Demonstration (RTD)," Research \& Technology 1999. NASATM-2000-209639, March 2000, p. 163-164.

10. Baity, F. W.. et al., "Design of RF Systems for the RTD Mission VASIMR." ORNL/CP-103576, Apr 12, 1999

11. Sackett, Lester L., Malchow, Harvey L., and Edelbaum, Theodore N.. "Solar Electric Geocentric Transfer with Attitude Constraints: Analysis," NASA CR-134927, Aug 01, 1975.

12. Jordan, Caroly'n E.. "NASA radiation belt models AP-8 and AE-8." Report AD-A223660. Sep 30, 1989.

13. Chetty, P.R.K., et al., "TOPEX Electrical Power System," $26^{\text {th }}$ Intersociety Energy Conversion Engineering Conference, August 4-9, 1991.
14. Hosken, Robert W., and Wertz, James, R., "Microcosm Autonomous Navigation System On-Orbit Operation," http://www.smad.com/analysis/mans I.html

15. Anonymous, http:/www-projet.est.cnes. fr:8060 JASON/MissionRequirements.html

16. Robertson, Brent, et al., "TRMM On Orbit Attitude Control System Performance," AAS-99-073, Jan 01. 1999.

17. Jenkin, Alan B., "Attitude Maneuvers of a Solar-Powered Electric Orbital Transfer Vehicle," AAS PAPER 91481, Jan 01, 1992.

18. Anonymous, http:/www.spectrolab.com/

19. Ehsani, M. and Salim. A. "Flawless IN-orbit Performance of Lockheed Martins' Premier A2100 Electrical Power Subsysten for Communications Satellites," AIAA-2000-2809, $35^{\text {th }}$ Intersociety Energy Conversion Engineering Conference. Las Vegas, NV. Jul 24-28, 2000 .

20. Anonymous, hitp:/www.hughespace.com/ factsheets $/ 702 / 702 . h \mathrm{tml}$

21. Suzuki, Akio, "High-Efficiency Silicon Space Solar Cells," Solar Energy Materials and Solar Cells, Vol. 50, 1998, p. 289-303.

22. Jang. Jeffrey. et. al., "Recent Progress in Amorphous Silicon Alloy Leading to $13 \%$ Stable Cell Efficiency," $26^{\text {th }}$ IEE PVSC, Anaheim, CA. Sep 29-Oct 3, 1997.

23. Oneill, Mark, ENTECH Inc., personal communication, March 2000

24. Murphy, David $M$. and Allen, Douglas M., "SCARLET Development, Fabrication and Testing for the Deep Space 1 Spacecraft," 32nd Intersociety Energy Conversion Engineering Conference Proceedings, paper no. 97539. Aug 1997.

25. Jones, P. Alan, et al., "A high specific power solar array for low to mid-power spacecraft," Proceedings of the 12th Space Photovoltaic Research and Technology Conference (SPRAT 12). May 01, 1993, p. 177-187.

26. Plaut, J. J. and Spencer. D. A.. "Mission Plan for the Mars Surveyor 2001 Orbiter and Lander," Workshon on Mars 2001. Integrated Science in Preparation for Sample Return and Human Exploration, Jan 01, 1999, pp. 83.

27. Castell, Karen and Wingard, Robert, "Recent Advances in Power System Design at GSFC," $34^{\text {th }}$ Intersociety Energy Conversion Engineering Conference, SAE99-01-2534, Vancouver, British Columbia, Canada, Aug 1-5, 1999.

28. Tada, H. Y. et al., "Solar Cell Radiation Handbook," NASA CR-169662, Nov01, 1982.

29. Anspaugh, B. E. "GaAs Solar Cell Radiation Handbook." NASA-CR-203421, Jul 01, 1996

30. Cour-Palais, B. G., "Meteoroid Environmenı Model -1969 (Near Earth to Lunar Surface)," NASA SP 8013, 1969.

31. Kessler, D. J, et al., "Orbital Debris Environment for Spacecraft Designed to Operate in Low Earth Orbit," NASA TM-100471, April 1989.

32. Kessler, D. J., et al., "A Computer-Based Orbital Debris Model for Spacecraft Designs and Observations in Low-Earth Orbit," NASA TM-104825, Nov 1, 1996.

33. Eichelberger. R. J., and Kineke, J. H., Jr., Hypervelocity Impact," SPRINGER-VERLAG, Jan 1, 1967, p. 659-692

34. Myre, Craig A., "Hypervelocity Particle Impact Testing of Solar Array Coupons," Preliminary Information Report \#259. NASA Lewis Research Center, May 30, 1991.

35. Hoffman, David J.. et al., "Thin-Film Photovoltaic Solar Array Parametric Assessment," AIAA-2000-2919, 35 ${ }^{\text {th }}$ Intersociety Energy Conversion Engineering Conference, Las Vegas, NV Jul 24-28, 2000

36. Hamley, John A., et al., "Hall Thruster Direct Drive Demonstration," paper AIAA 97-2787, 33 $3^{\text {rd }}$ AIAA/ASME SAE/ASEE Joint Propulsion Conference and Exhibit, Seattle Washington. Jul 6-9, 1997.

37. Wertz, James R. and Larson, Wiley J., Space Mission Analysis and Design, $3^{\text {rd }}$ Ed., Microcosm Press, Torrance, CA and Kluwer Academic Publishers, Boston, MA. Sec. 11-1, 1999. 


\begin{tabular}{|c|c|}
\hline Parameter & Requirement \\
\hline $\begin{array}{l}\text { Orbit Type } \\
\text { Inclination }\left(^{\circ}\right) \\
\text { Initial Altitude }(\mathrm{km}) \\
\text { Final Altitude }(\mathrm{km})\end{array}$ & $\begin{array}{c}\text { Near Circular } \\
28.45 \text { or } 51.6 \\
400 \\
\sim 5 \text { Earth Radii }\end{array}$ \\
\hline Initial Mass (kg) & 1500 \\
\hline Transfer Time (yrs) & $\leq 1$ \\
\hline $\begin{array}{l}\text { Microsats } \\
\text { Number } \\
\text { Mass (kg) } \\
\text { Drop-off Altitudes (km) }\end{array}$ & $\begin{array}{c}4 \\
25 \text { each } \\
2000,12000,22000,32000\end{array}$ \\
\hline $\begin{array}{c}\text { Thruster System } \\
\text { Power Input (kW) }\end{array}$ & 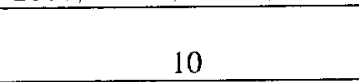 \\
\hline $\begin{array}{l}\text { Hall Thruster } \\
\text { Isp (sec) } \\
\eta \text { (PPU \& thruster) } \\
\text { Propellant }\end{array}$ & $\begin{array}{r}2100 \\
0.54 \\
\text { xenon } \\
\end{array}$ \\
\hline $\begin{array}{l}\text { VASIMR Thruster } \\
\text { Isp (sec) } \\
\eta \text { (PPU \& thruster) } \\
\text { Propellant }\end{array}$ & $\begin{array}{c}10000 \\
0.5 \\
\text { hydrogen }\end{array}$ \\
\hline $\begin{array}{l}\text { Operating Thruster Type } \\
\text { Versus Mission Altitude } \\
400 \text { to } 9000 \mathrm{~km} \\
9000 \text { to } 20000 \mathrm{~km} \\
20000 \mathrm{~km} \mathrm{\&} \mathrm{above}\end{array}$ & $\begin{array}{l}\text { Hall } \\
\text { VASIMR } \\
\text { Hall }\end{array}$ \\
\hline
\end{tabular}

Table 1. Mission Requirements \& Vehicle Definition

\begin{tabular}{|c|c|c|c|}
\hline $\begin{array}{c}\text { Option } \\
\text { Description }\end{array}$ & $\begin{array}{l}\text { Cell } \eta \\
\text { 1-Sun, } \\
\text { AM0 } \\
28^{\circ} \mathrm{C} \\
(\%) \\
\end{array}$ & $\begin{array}{c}\text { Calculated } \\
\text { Panel } \\
\text { Mass* } \\
(\mathrm{kg} / \mathrm{m} 2) \\
\end{array}$ & $\begin{array}{c}\text { Estimated } \\
\text { Mechanism } \\
\text { \& Structure } \\
\text { Mass }^{\mathbf{4}} \\
\left(\mathbf{k g} / \mathbf{m}^{2}\right) \\
\end{array}$ \\
\hline $\begin{array}{l}\text { 1. Rigid panel, } \\
\text { cascade GaAs cells }\end{array}$ & 25 & 2.74 & $\begin{array}{c}10 \% \text { of } \\
\text { panel mass }\end{array}$ \\
\hline $\begin{array}{l}\text { 2. Rigid panel, side } \\
\text { reflectors, cascade } \\
\text { GaAs cells }\end{array}$ & 25 & 2.88 & $\begin{array}{c}10 \% \text { of } \\
\text { panel mass }\end{array}$ \\
\hline $\begin{array}{l}\text { 3. Flexible panel. } \\
\text { cascade GaAs cells }\end{array}$ & 25 & 1.64 & 0.6 \\
\hline $\begin{array}{l}\text { 4. Flexible panel, } \\
\text { high } \eta \text {, 4-mil Si cells }\end{array}$ & 17 & 1.16 & 0.6 \\
\hline $\begin{array}{l}\text { 5. Flexible } 5 \text {-mil } \\
\text { stainless steel panel, } \\
\text { amorphous SiGe cells }\end{array}$ & $\begin{array}{c}9 \\
\text { (stable) }\end{array}$ & 1.06 & 0.6 \\
\hline $\begin{array}{l}\text { 6. Rigid panel, rigid } \\
\text { linear concentrators, } \\
\text { cascade GaAs cells }\end{array}$ & 25 & 2.64 & $\begin{array}{r}10 \% \text { of } \\
\text { panel mass } \\
\end{array}$ \\
\hline $\begin{array}{l}\text { 7. Flexible panel, } \\
\text { flexible linear } \\
\text { concentrators, } \\
\text { cascade GaAs cells }\end{array}$ & 25 & 0.88 & 0.6 \\
\hline $\begin{array}{l}\text { 8. Flexible gore, } \\
\text { cascade GaAs cells }\end{array}$ & 25 & 1.43 & 0.3 \\
\hline $\begin{array}{l}\text { 9. Flexible gore, } \\
\text { high } \eta \text {. 4-mil Si cells }\end{array}$ & 17 & 0.96 & 0.3 \\
\hline
\end{tabular}

Table 2. PV Array Technology Options

* -10-mil coverslides. GaAs cells with 5.5-mil Ge substrates

$\Psi$ - Power harness and SADA masses calculated separately and included in PV Array wing mass total.

\begin{tabular}{|c|c|c|}
\hline Design Feature & NiH2 & Li Ion \\
\hline Maximum Cell Voltage (V) & 1.5 & 4.1 \\
\hline $\begin{array}{c}\text { Minimum Eclipse Time Bus Voltage } \\
(\% \text { of Sun Time Voltage Setpoint) }\end{array}$ & 75 & 75 \\
\hline \# of Cycles & 1000 & 1000 \\
\hline Recharge Ratio & 1.1 & 1.0 \\
\hline \# of Failed (Open-Circuited) Cells & 1 & 1 \\
\hline By-pass Diode Voltage Drop (V) & 0.7 & 0.7 \\
\hline $\begin{array}{c}\text { Battery Round Trip Energy Efficiency } \\
(\%)\end{array}$ & 79 & 85 \\
\hline $\begin{array}{c}\text { Design Temperature Limits }\left({ }^{\circ} \mathrm{C}\right) \\
\text { Minimum } \\
\text { Maximum }\end{array}$ & 0 & -5 \\
\hline
\end{tabular}

Table 3. Battery Design Inputs

\begin{tabular}{|c|c|}
\hline Parameter & Options \\
\hline $\begin{array}{c}\text { Solar Cell Ceria-Doped } \\
\text { Coverslide Thickness }\end{array}$ & 4-mil through 32-mil \\
\hline PV Array Technology & See Table 2. \\
\hline Battery Technology & $\mathrm{NiH} 2, \mathrm{Li}$ Ion \\
\hline PMAD DC Voltage & $28-\mathrm{V}, 50-\mathrm{V}, 120-\mathrm{V}$ \\
\hline Mission Orbit Inclination & $28.45^{\circ}, 51.6^{\circ}$ \\
\hline
\end{tabular}

Table 4. Parametric Study Trade Space 


\begin{tabular}{|c|c|c|c|c|c|c|c|c|c|c|}
\hline \multirow[t]{2}{*}{ Option } & \multirow{2}{*}{$\begin{array}{c}\text { EPS } \\
\text { Mass } \\
\text { (kg) }\end{array}$} & \multirow{2}{*}{$\begin{array}{c}\text { Array } \\
\text { Mass } \\
\text { (kg) }\end{array}$} & \multirow{2}{*}{$\begin{array}{l}\text { Wing } \\
\text { Area } \\
\text { (m2) }\end{array}$} & \multicolumn{3}{|c|}{$\begin{array}{l}\text { Specific Power } \\
(W / k g)\end{array}$} & \multirow{2}{*}{$\begin{array}{c}\text { In-Service, } \\
\text { Cell BOL } \eta \\
(\%)\end{array}$} & \multirow{2}{*}{$\begin{array}{c}\text { Typical } \\
\text { Cell } \\
\text { BOL Temp. } \\
\left({ }^{\circ} \mathrm{C}\right) \\
\end{array}$} & \multicolumn{2}{|c|}{$\begin{array}{c}\log _{10} \mathrm{DENI} \text { Fluence } \\
(\# 1-\mathrm{MeV} \mathrm{e} / \mathrm{cm} 2)\end{array}$} \\
\hline & & & & Panel & Array & EPS & & & Current & Voltage \\
\hline 1 & 258 & 167 & 24.9 & 104 & 80 & 40 & 21.7 & 45 & 14.62 & 14.79 \\
\hline 2 & 188 & 99 & $\begin{array}{l}13.8 \\
29.5^{\psi}\end{array}$ & 198 & 133 & 55 & 19.8 & 105 & 14.60 & 14.77 \\
\hline 3 & 220 & 130 & 25.3 & 175 & 104 & 47 & 21.7 & 45 & 14.71 & 14.88 \\
\hline 4 & 313 & 218 & 56.4 & 165 & 68 & 33 & 10.9 & 60 & 15.47 & 15.82 \\
\hline 5 & $\mathrm{~N} / \mathrm{S}$ & $\mathrm{N} / \mathrm{S}$ & $\mathrm{N} / \mathrm{S}$ & 108 & 29 & 11 & 4.3 & 110 & $>15.33$ & $>16.06$ \\
\hline 6 & 280 & 191 & 23.5 & 98 & 68 & 37 & 22.2 & $\begin{array}{l}65 \text { - cell } \\
20 \text { - lens }\end{array}$ & 14.18 & 14.36 \\
\hline 7 & 180 & 89 & 24.7 & 330 & 150 & 58 & 21.7 & $\begin{array}{l}70 \text { - cell } \\
25 \text { - lens } \\
\end{array}$ & 14.55 & 14.72 \\
\hline 8. & 195 & 105 & 25.3 & 199 & 124 & 53 & 21.7 & 45 & 14.79 & 14.95 \\
\hline 9 & 298 & 199 & 70.8 & 200 & 87 & 35 & 10.0 & 65 & 16.03 & 16.47 \\
\hline
\end{tabular}

* - Array is comprised of two wings Table 5. Effects of Solar Array Technology Option

$\Psi$ - Array plus side reflector area. N/S - No Solution

\begin{tabular}{|c|c|c|}
\hline Design Feature & NiH2 & Li Ion \\
\hline \# Series Cells & 81 & 30 \\
\hline Cell Capacity (Amp-hrs) & 10 & 10 \\
\hline Design Depth-of-Discharge (\%) & 75 & 50 \\
\hline Design Charge Rate & $\mathrm{C} / 3.0$ & $\mathrm{C} / 3.3$ \\
\hline Design Discharge Rate & $\mathrm{C} / 2.1$ & $\mathrm{C} / 2.1$ \\
\hline Trickle Charge Rate & $\mathrm{C} / 50$ & $\mathrm{C} / 50$ \\
\hline Battery Mass (kg) & 35.6 & 12.5 \\
\hline Battery Volume (m3) & 0.0537 & 0.0069 \\
\hline Maximum Heater Power (W) & 9 & 0 \\
\hline Maximum Cooling Load (W) & 2 & 2 \\
\hline
\end{tabular}

Table 6. Battery Design Results

\begin{tabular}{|c|c|c|c|}
\hline $\begin{array}{c}\text { Design } \\
\text { Characteristic } \\
\end{array}$ & 120-VDC & 50-VDC & 28-VDC \\
\hline EPS Masses (kg) & & & \\
\hline Solar Array & 167.2 & 198.6 & 253.2 \\
\hline Battery & 35.6 & 26.2 & 33.5 \\
\hline PMAD Boxes & 51.5 & 72.4 & 116.4 \\
\hline PMAD Cabling & 4.1 & 10.6 & 20.7 \\
\hline Total & 258.4 & $\overline{307.8}$ & $\overline{423.8}$ \\
\hline PPU Current (Amp) & 84 & 205 & 382 \\
\hline Array Wing Area $(\mathrm{m} 2)$ & 24.9 & 26.6 & 31.7 \\
\hline \# Solar Cells per String & 64 & 28 & 18 \\
\hline \# Strings per Wing & 138 & 336 & 624 \\
\hline $\begin{array}{c}\text { Battery Cell Capacity } \\
\text { (Amp-hrs) }\end{array}$ & 10 & 20 & 50 \\
\hline
\end{tabular}

Table 7. Design Impacts of PMAD Voltage

\begin{tabular}{|c|c|c|c|c|c|c|c|}
\hline \multirow[b]{2}{*}{ Option } & \multirow{2}{*}{$\begin{array}{c}\text { Max Space- } \\
\text { craft Mass } \\
\text { Moment } \\
\text { of Inertia } \\
\text { (kg-m2) } \\
\end{array}$} & \multirow{2}{*}{$\begin{array}{c}\text { Max Sum } \\
\text { Environ. } \\
\text { Torque } \\
\text { (N-m) }\end{array}$} & \multirow{2}{*}{$\begin{array}{c}\text { Max Roll } \\
\text { Steering } \\
\text { Torque } \\
\text { (N-m) } \\
\end{array}$} & \multirow{2}{*}{$\begin{array}{c}\text { Max Sum } \\
\text { Environ. } \\
\text { Momentum } \\
\text { per Orbit } \\
\text { (N-m-sec) } \\
\end{array}$} & \multirow{2}{*}{$\begin{array}{c}\text { Max Roll } \\
\text { Steering } \\
\text { Momentum } \\
\text { per Orbit } \\
\text { (N-m-sec) } \\
\end{array}$} & \multicolumn{2}{|c|}{$\begin{array}{c}\text { \# Momentum } \\
\text { Dumps per Day }\end{array}$} \\
\hline & & & & & & $\begin{array}{c}\text { BOL at } \\
400 \mathrm{~km} \\
\text { alt. }\end{array}$ & $\begin{array}{c}\text { EOL at } \\
35000 \mathrm{~km} \\
\text { alt. }\end{array}$ \\
\hline 1 & 13289 & 0.0312 & 0.1811 & 81.24 & 21.73 & 32 & 9 \\
\hline 2 & 5685 & 0.0139 & 0.0775 & 50.50 & 9.30 & 19 & 9 \\
\hline 3 & 10727 & 0.0259 & 0.1462 & 73.49 & 17.54 & 28 & 9 \\
\hline 4 & 32977 & 0.0755 & 0.4494 & 155.39 & 53.92 & 65 & 9 \\
\hline 5 & $\mathrm{~N} / \mathrm{S}$ & $N / S$ & $\mathrm{~N} / \mathrm{S}$ & $\mathrm{N} / \mathrm{S}$ & $\mathrm{N} / \mathrm{S}$ & $\mathrm{N} / \mathrm{S}$ & $\mathrm{N} / \mathrm{S}$ \\
\hline 6 & 14482 & 0.0327 & 0.1973 & 79.32 & 23.68 & 32 & 9 \\
\hline 7 & 7685 & 0.0202 & 0.1047 & 67.67 & 12.57 & 25 & 9 \\
\hline 8 & 4997 & 0.0151 & 0.0681 & 63.34 & 8.17 & 22 & 9 \\
\hline 9 & 18258 & 0.0503 & 0.2488 & 144.02 & 29.86 & 54 & 9 \\
\hline
\end{tabular}

Table 8. EPS Design Impacts to ACS 


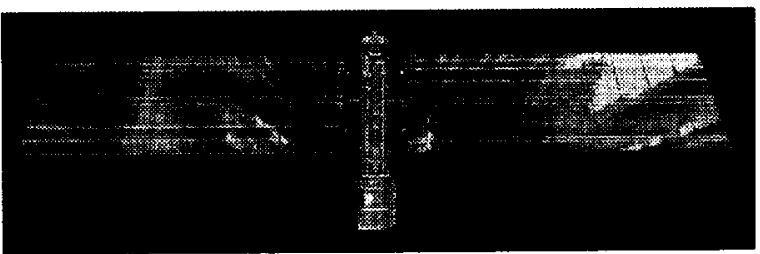

Figure 1. Conceptual RTD Spacecraft

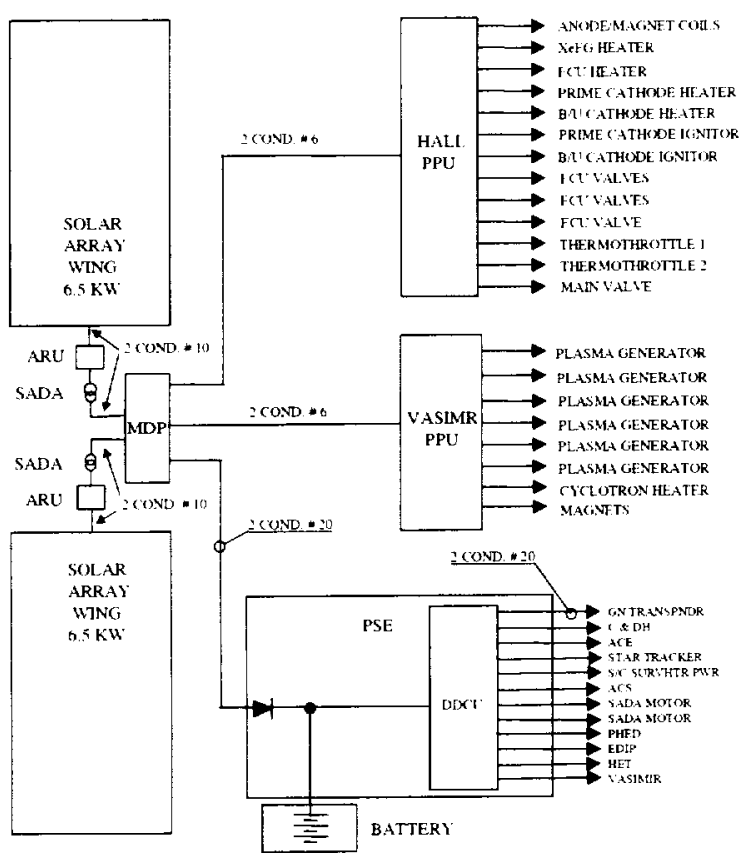

Figure 2. PMAD Architecture

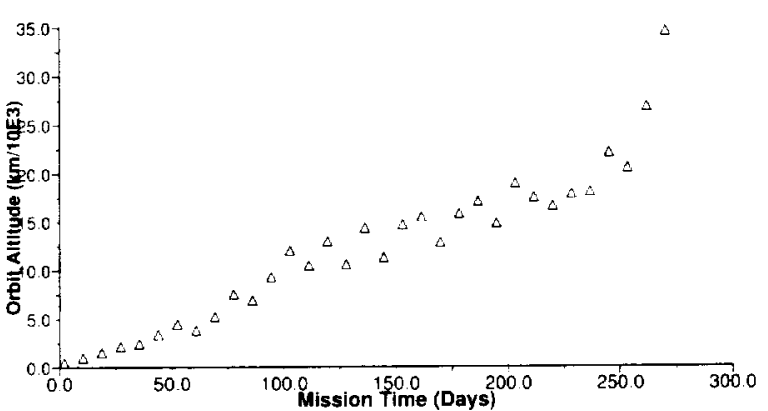

Figure 3. Mission Orbit Altitude History

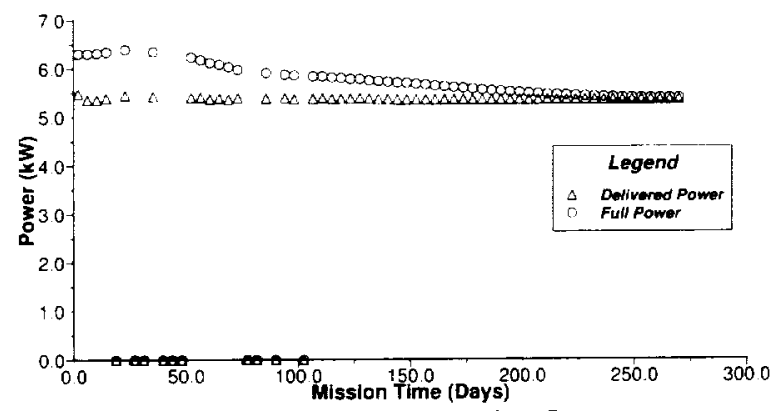

Figure 4. Solar Array Wing Power

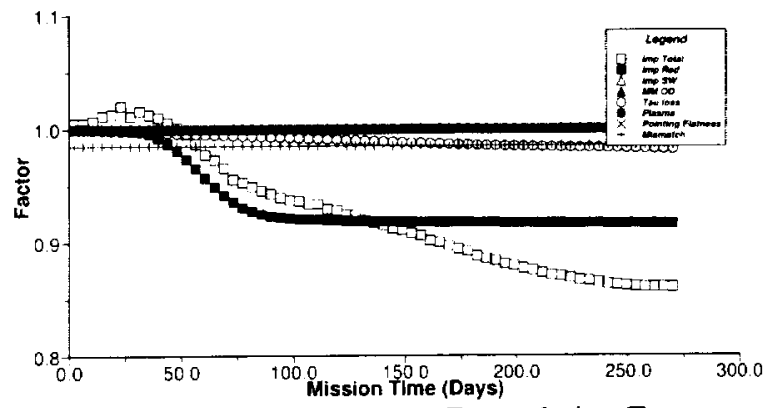

Figure 5. Solar Cell Current Degradation Factors

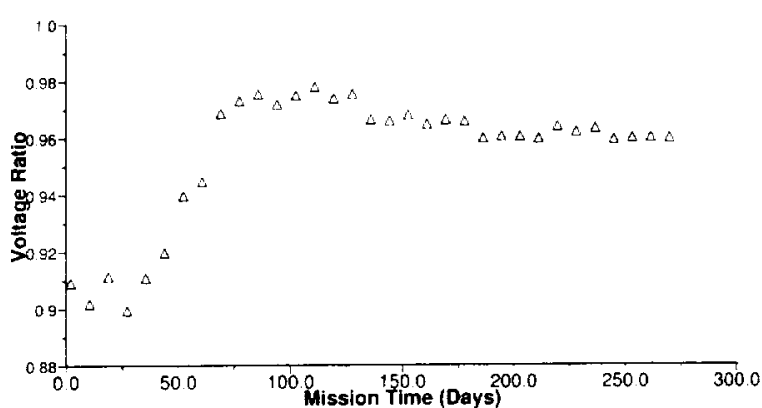

Figure 6. Solar Cell Vop/Vmp Ratio

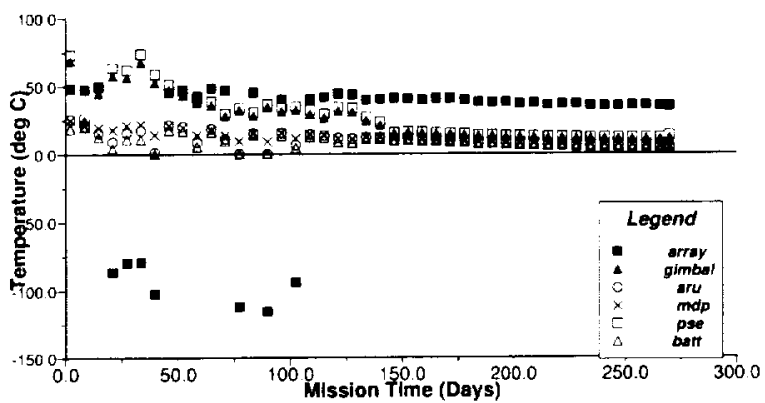

Figure 7. EPS Component Temperatures

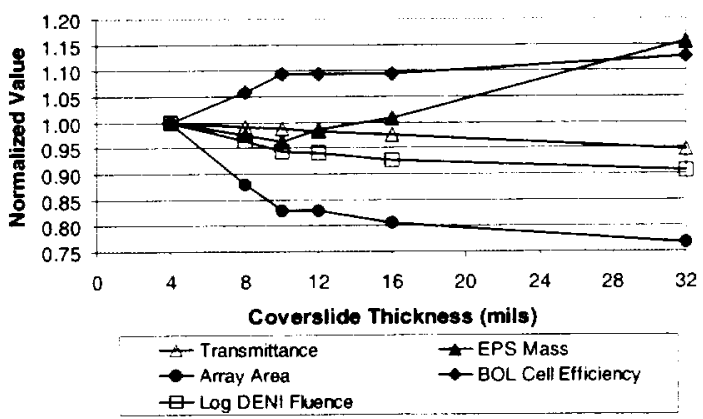

Figure 8. Effects of Solar Cell Coverslide Thickness 


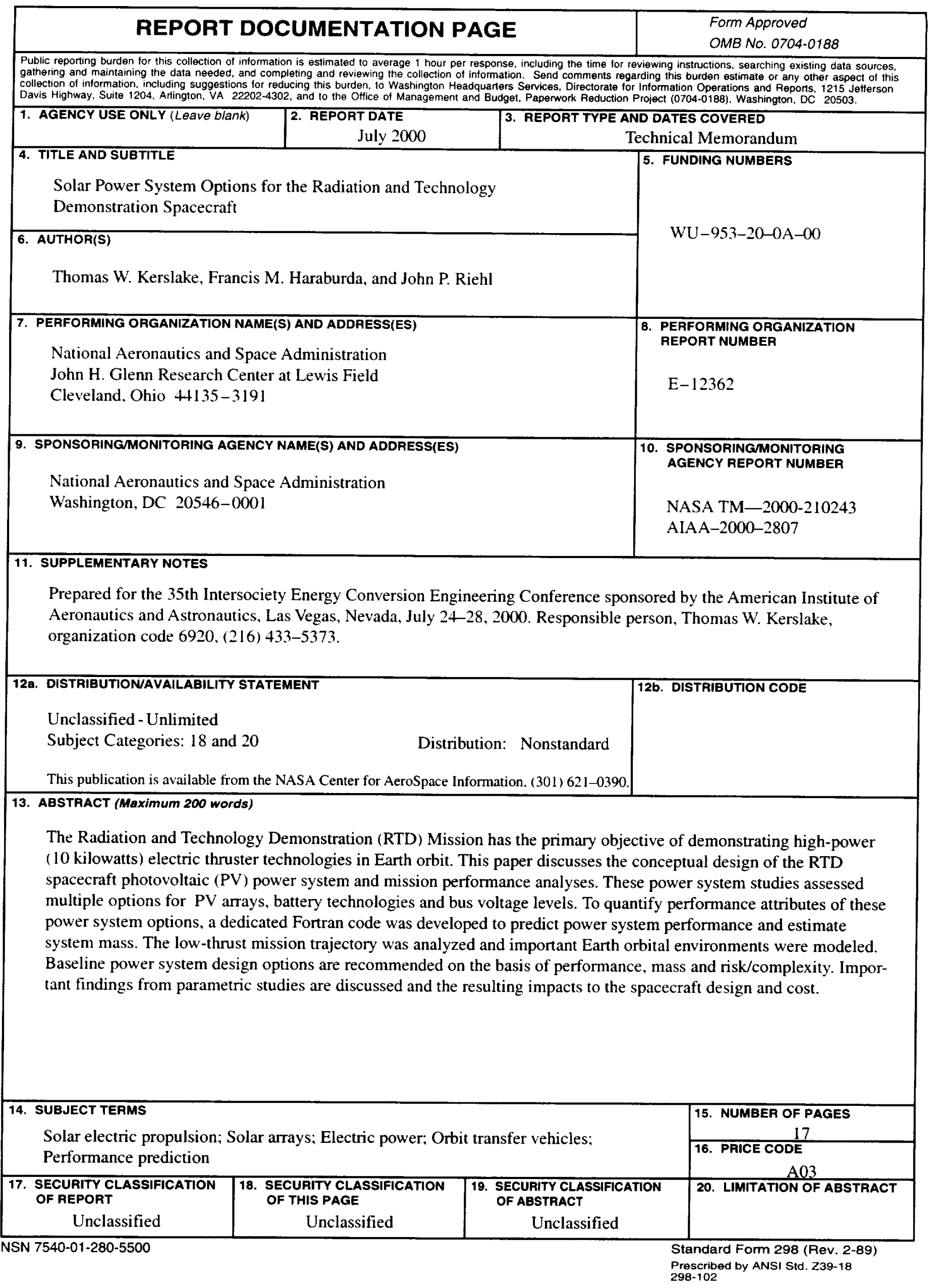



 